\title{
A Case Study of Chinese Students Learning Thai as a Foreign Language: Flanders Interaction Analysis Category System
}

\author{
${ }^{1}$ Faculty of Liberal Arts, Mahidol University, Thailand \\ *Corresponding author's email: zhaokailing644@ gmail.com \\ * (D): https://orcid.org/0000-0002-1878-6043 \\ do): https://doi.org/10.54855/ijte.222110
}

Kailing Zhao ${ }^{1 *}$, Kornsiri Boonyaprakob ${ }^{1}$

Received: 11/12/2021

Revision: 06/01/2021

Accepted: 09/01/2022

Online: $12 / 01 / 2022$

ABSTRACT

Interaction in foreign language classrooms has been regarded as a key factor in enhancing learning outcomes (Allwright, 1984; Ginting, 2017; Hanum, 2016). This study examined interactions in a specific university classroom context in Thailand where 28 Chinese students were learning Thai as a foreign language with a Thai teacher. It employed a mix-method design. Quantitative data were gathered based on a modified Flanders' model (Flanders Interaction Analysis Category System or FIACS), and the qualitative data were gathered from classroom observations. The analysis of 90-minute video records and field notes from the observations of three classes reveal the domination of teacher's talk $(77.59 \%)$, and the minimal students' talk (6.16\%). Besides, silence time occupies $16.25 \%$. Out of the total of 22 categories of interaction, no student talk can be categorized as an initiation of talk, and no teacher talk can be categorized as procedural lectures and assigning homework. Characteristics of the interaction varied according to the quantity and

Keywords: students' perceptions, videobased tasks, the American English File series categories of talk. Transcription of verbatim from the videos reveals details of the interaction. Findings suggest that quantity, category, and characteristics of talk are interrelated and must all be improved together to increase the quality of interaction to affect student learning outcomes.

\section{Introduction}

According to Brown (2000), and Thomas (1987), interaction is a collaborative process of exchanging ideas, feelings, and thoughts between two or more persons, which will create reciprocal effects on each other. It is also a process of information exchange between multiple objects; thus, individuals express their own views and include receiving and understanding the information transmitted by other interlocutors and responding to it (Hadfield \& Hadfield, 2008, River, 1987). When one interlocutor asks a question to another, for instance, the other interlocutor thinks about the question after receiving the information and then gives a reply,

CITATION | Zhao, K., \& Boonyaprakob, K. (2021). A Case Study of Chinese Students Learning Thai as a Foreign Language: Flanders Interaction Analysis Category System. International Journal of TESOL \& Education, 2(1), 
which serves as the input information of the interlocutor.

Flanders (1961) defined teaching as an interactive process where both teachers and students participate. In this process, teachers and students interact with each other and among the students themselves. Interaction is an important part of education and a key factor in teaching outcomes (Allwright, 1984; Ginting, 2017; Hanum, 2017). Allwright (1984) states that successful pedagogy should involve the successful management of classroom interaction. As Hanum (2017) states, interaction can help the teaching and learning process run smoothly, help teachers reach teaching objectives, and enhance the outcome of learning. It is also conducive to the improvement of student's communication ability, cognitive ability, and social ability (Brown \& Lee, 2015).

Specifically, interaction plays a significant role in language classrooms in both the teaching and learning processes. Thus, researchers and educators have been of great concern for many years (Afrin, 2018; Ginting, 2017; Nunan, 1991). According to Allwright (1984), the learning process can even be carried out without a pre-designed syllabus and textbooks, but it can never be carried out without interaction. Teachers can learn about students' understanding and mastery of teaching according to their interaction and choose suitable, understandable, and meaningful input information for them in the classroom (Harmer, 2008).

Interaction also plays an important role in the acquisition of a language, including second language (SL) and foreign language (FL). It provides students with real language context and basic input sources (Afrin, 2018; Long, 1996). With the idea that language is learned to be used, interaction in language classrooms provides students with opportunities to practice the target language and produce comprehensible output (Hedge, 2000). It is an effective way to enhance speaking skills (Afrin, 2018; Taous, 2013), which is a crucial part of the language learning process (Kayi, 2006). Moreover, students can seize the opportunity to test their language proficiency through interaction with teachers and classmates. They can also have opportunities to get valuable feedback from teachers and classmates to help improve their language proficiency (Hedge, 2000). Being actively engaged and interacting during the communication process in the language classroom helps facilitate students' second language acquisition (Nunan, 1991).

\subsection{Significance of the study}

Firstly, the study examined an environment where Chinese students were learning Thai as a FL in Thailand. Chinese students have become a major group of international students in Thailand since 2006 (Luo, 2016). Like many international students who study abroad, this specific group also encounters a lot of problems (Nghiem et al., 2021). The language barrier is one of the biggest stressors of their living in Thailand (Bin, 2009). In addition, there are some factors involved in Chinese students' willingness to learn Thai, including their motivation and perceptions toward the language ( Fang and Chalermnirundorn, 2019; Ye, 2020). Hence, the language learning situation of Chinese students studying in Thailand is a meaningful research topic that has rarely been explored. Importantly, unlike previous studies that apply FIACS as a framework and employ only quantitative data, this study merges both qualitative and quantitative data. As is well-known, quantitative studies can capture a phenomenon, but their analysis is not deep enough, ignoring the participants' and investigators' personal experience and expression (Rahman, 2017). With the mixed-method design, this study can provide meaningful insights and suggestions for teaching and learning of Thai language to Chinese 
students residing in Thailand. In-depth findings can also enrich the theoretical system in the field of language teaching and learning, bringing more practical suggestions to FL classrooms.

\subsection{Research objective}

Holding on to the significance and contributions of interaction on teaching, learning, and language development, this study specifically inquired into the quantity, characteristics, and categories of teachers' talk and students' talk. This is based on the application of the concept of influential Flanders Interaction Analysis Category System or FIACS (Flanders, 1961; Flanders, 1966) and the modified FIACS (Hao, 2007; Mu, Lu \& Wang, 2014; Blosser, 1975).

\subsection{Scope of this study}

This case study was participated by a limited number of Chinese students and one Thai teacher in a specific college context in Thailand. Students' mother tongue is Chinese, and they study Thai as an FL. Based on the demographic data provided by the participants, about half of them had learned the Thai language as pre-college students in the target university for one year or from other language schools. The other half, however, had no background in the Thai language. The teacher's mother tongue is Thai, and she speaks English as a foreign language. During the data gathering process, the language of instruction was mainly Thai, with little use of English. Genders of the participants are not regarded as a variable in this study. The research environment has its own particularity as the students were studying FL in the target language context. With this scope of the study, the generalization of the research results must be taken with caution.

\section{Literature review}

\subsection{Conceptual Framework}

The design of this study adheres to the concept of influential Flanders Interaction Analysis Category System or FIACS (Flanders, 1970) and the modified FIACS (Hao, 2007; Mu, Lu \& Wang, 2014; Blosser, 1975). The FIACS is one of the common, widely used systems as a conceptual framework to guide study on classroom interaction. It was created by Ned. A. Flanders at the University of Minnesota in the 1950s. The FIACS is primarily concerned with the emotional climate of the classroom resulting from verbal interaction between teacher and students (Evans, 1970). The original FIACS consists of three sub-categories: "Teacher Talk", "Student Talk" and "Silence". "Teacher Talk" is categorized as "Direct Talk" and "Indirect Talk". "Indirect Talk" includes "Accept Feelings", "Praise or Encouragement", "Accepts or Uses Ideas of Pupils", and "Asking Questions". "Direct Talk" contains "Lecture", "Giving Directions", and "Criticizing or Justifying Authority". "Student Talk" includes "Pupil talk: response" and "Pupil talk: initiation". The last category, "Silence," is about silence and confusion.

The original Flanders system excluded non-verbal interaction. Only the verbal interaction is taken into consideration based on three theoretical assumptions. Firstly, verbal interaction is predominant in a normal classroom situation (Flanders, 1965), and it can serve as a sufficient sample of all classroom behaviors (Singh, Sharma, \& Upadhya, 2008). Secondly, although the 
use of spoken language sometimes relies on non-verbal gestures, verbal behavior can be observed with higher reliability than non-verbal behavior (Amatari, 2015). Teachers' classroom verbal behavior can be objectively observed by using observation techniques. The observation techniques can record natural behavior patterns, which also allows the measurement process to produce minimal interference to the normal activities of individuals. Thirdly, the teacher's verbal behavior is consistent with his/her non-verbal behavior, which is consistent with the teacher's total behavior (Flanders, 1966).

\subsection{Application of FIACS in FL classroom}

Interaction in the classroom has been proved to have an important relationship with foreign language acquisition (Tsui, 2001; Afrin, 2018). FIACS, as one commonly used instrument, has also been widely used in the field of interaction study in FL classrooms. Through the application of FIACS, the time and type of teacher and student talking in the classroom and the characteristics of interaction can be reflected. The results are helpful to the improvement of the quantity and quality of classroom interaction. Most of the previous studies included in this review employed Flanders Interaction Analysis Category System (FIACS). These studies provide useful information focusing on the issues of balance of interaction between teachers and students, opportunities for students' participation, and their willingness to initiate interaction.

Concerning the issues of balance of interaction between teachers and students, previous studies have shown that rather than being a collaborative process (River, 1987), interaction in the classroom has been found dominated by teachers because they play a major role in managing the whole language classroom. Research studies using FIACS (Adaba, 2017; Carless, 2008; Chaudron, 1988; Fazio \& Lyster, 1997; Gupta, 2004; Hullen, 1989; Nunan, 1991; Sakui, 2004) have shown that teachers talk most of the time in class while students are rarely given opportunities to talk. Teachers have power to distribute learning opportunities for students due to their institutional status (Hall, 1997). They also took the role of a controller and major speaker during teaching (Mulyati, 2013). They exploit time for their own speaking and controlling classroom activities (Afrin, 2018). They had time constraints to cover some class materials included in the examinations and reach the teaching objectives (Indoshi, Bett, and Odera, 2009). As a result of their dominant role, teachers neither adequately organize pair nor group learning opportunities (Gündüz, 2014). This even reduces opportunities for students to interact among themselves.

Regarding opportunities for students, Afrin (2018) and Gündüz (2014) found that the content of students' talk was mostly to answer the teacher's questions, not to ask or answer voluntarily. Studies conducted in Thailand (Cheewagaroon, 2011; Wiriyachitra, 2002) also show that teachers do not give students opportunities to practice speaking in class, and the content of the course focuses only on grammatical structure. This results in students' lack of opportunities and ability to use English for communication.

As for students' willingness to initiate interaction, Romanel and Kundu (1993) found students to avoid answering questions despite the chance for students to talk. Their reason to refrain was to protect themselves from being punished if they give wrong answers or make mistakes. Bonavetti (2015), Sundari (2017), and Almohizea (2018) also found students to have chances 
to communicate with everyone in the class, but they were unwilling and reluctant to speak on their own initiative. Despite opportunities provided, studies have also shown that some Asian students are passive and quiet in language classrooms, which is believed to be caused by cultural factors (Chowdhury, 2005).

\subsection{Studies to improve the quality of classroom interaction}

In accordance with the issues raised in the literature, many researchers have put efforts to improve interaction in the classroom so that it brings about benefits for teaching and learning. These studies have revealed an association between the quality of interaction and the students' achievement, their social performance, and language learning enhancement.

Allen and associates (2011) explored the relationship between the teacher-student interaction and the achievement of secondary school students. Data was gathered from one secondary school with 78 teachers and 2237 students. A web-mediated approach was implemented as an intervention to improve the quality of interaction between the teachers and students. Findings suggest a link between the improvement of the quality of interaction between teachers and students and the student's achievement. In another study, Allen and associates (2013) explored the teacher interactions with adolescent students and found the quality of interaction to be a predictor of student learning outcomes. The quality of interaction described in the study includes how the teachers are sensitive to the adolescent students' needs and recognize the student needs for interaction with their peers and independence in activity participation. In addition to learning achievement, teacher-student interaction affected students' cognitive, social, and emotional growth and enhanced their mental well-being. Another study on teacherstudent interaction by Hughes, Cavell and Willson (2001) with 993 third-grade and fourth-grade students showed that the interaction affected students' social performance by affecting the perceptions of each other. Conflicting teacher-student interaction can lead to peer rejection, which would significantly impact the self-esteem of students and lead to several negative social outcomes (Hughes et al., 1999).

In addition to the effects of classroom interaction on students' achievement improvement and social behavior development, interaction in FL classrooms can enhance students' language learning. Interaction helps promote the development of language learning as shown in Long's study in 1996. Long (1996) explored the role of corrective feedback (CF) and negotiation of meaning (NOM) in classroom interaction between native speakers and second language (L2) students and among L2 students. The study adopted a pretest-treatment-posttest design with six participants: two native English speakers, two Chinese L1 speakers with high English proficiency, and two Chinese L1 speakers with low English proficiency. The error rate of all students was found to decrease from pretest to post-test, especially the Chinese L1 speakers with low English proficiency. This supports the view that $\mathrm{CF}$ and NOM can promote the development of the L2 (Long, 1996). Speaking is a crucial part of the language learning process (Kayi, 2012), and interaction is an effective way to enhance speaking skills. Taous (2013) investigated the role of classroom interaction in improving speaking skills in language classrooms with three different groups of students from Local Mean Decomposition (LMD) third-year classes at Biskra University. By observing the classroom and interviewing the teacher, the researcher indicated that learner-learner interaction was one of the key factors in improving students' speaking skills. In Afrin's study (2018), classroom interaction was signified as necessary to develop students' speaking skills because it provided opportunities for students 
to practice their speaking skills in the classroom as they had inadequate opportunities to practice it outside the classroom.

\subsection{Research Questions}

To understand interaction in classrooms between Chinese students learning Thai as a foreign language and their teacher, and the interaction among the students themselves, this study was conducted to answer the research question:

What are the quantity, characteristics, and categories of teacher's talk and students' talk based on a modified FIACS in a Thai language class where Chinese college students are studying Thai as an FL?

\section{Methods}

\subsection{Pedagogical Setting \& Participants Recruitment}

This study was conducted at Hope University (pseudonym), which is located in northern Thailand. The volunteer participants were one Thai teacher and 28 Chinese students studying in their sophomore year of "Business Thai" majors from International College in the target university. The class where the research was conducted was purposely sampled as it was a context where Chinese students were studying Thai as a foreign language. Despite the university's purposive sampling procedure and convenience sampling, participation of the teacher and the students was voluntary. During the informed consent process, the researcher explained all the details about the research, all the participating procedures, and the rights of the participants.

\subsection{Design of the Study}

This study employed a mixed-method design that included collecting quantitative data using the FIACS scale to calculate the frequency, percentage, and ratio of teacher talk and student talk. The calculation reflects the quantity, characteristics, and categories of the talk. Qualitative data were also gathered from three classes using video records of lessons and field notes from observations.

\subsection{Research Instrument and data collection}

\subsubsection{The modified Flanders scale}

Even though the FIACS is one of the most applied instruments in interaction analysis, current scholars state that there are several limitations in the original FIACS. Firstly, FIACS does not classify lecturing, so it is impossible to analyze teachers' teaching more in-depth. Secondly, FIACS generalizes all the questions into "Ask questions", so the quality and nature of teachers' questions cannot be analyzed. Thirdly, the FIACS system does not involve the application of information technology in classroom teaching, while multimedia equipment is an important teaching tool in contemporary teaching (Mu, Lu, \& Wang, 2014). Fourthly, FIACS classifies silence or chaos in the classroom as the silence that is not helpful to teaching. In the real classroom, however, students need silent time to think independently and to complete tasks. This silence is considered helpful for teaching and learning. Fifth, in FIACS, teachers' teaching 
behavior is mainly observed, and only three items analyze students' behavior. In order to make up for the limitations of the original Flanders scale, Hao (2007), and Mu, Lu and Wang (2014) add more items to the scale.

According to Mu, Lu and Wang (2014), the 4th item, "Comments on students' answer," is added since it is another kind of response from teachers which is not covered in the original scale. Compared to the original FIACS, the modified scale classifies the 6th item, "Ask questions," into two sub-categories, "Ask open-ended questions" and "Ask closed questions," since they are two different types of questions in terms of purposes and forms (Blosser, P. E., 1975). As for the 7th item, "Lecturing" is divided into three sub-items: declarative lecture, procedural lecture, and technical lecture. Declarative lecture refers to teachers providing facts or opinions on content or steps. The procedural lecture refers to teachers' knowledge about the steps of producing behavior, such as teaching operation rules, experimental operations, for example. Technical lecture refers to the use of multimedia technology by teachers to cooperate with teaching, such as using slides while demonstrating and explaining technology-manipulated teaching content. The last item is "Silence". This is classified into three sub-categories: "Silence or confusion that contributes to teaching", "Silence or confusion that doesn't help teaching", and "Silence that couldn't be identified by observation" because silence can be either beneficial or detrimental to classroom teaching. Hao (2007), also adds a category on students' talk among themselves. The students' talk is categorized into "Teacher-student talk" and "Student-student talk" to tell the interaction between students and teacher and with peers apart. Additionally, individual and collective talk between teachers and students are analyzed.

As for this study, the modified FIACS (Hao, 2007; and Mu, Lu and Wang; 2014) are slightly adapted in terms of the details of sub-categories to make items more specific for data coding. The adoption includes: 1) adding of specific details of item 5 "Giving directions" to be "Giving directions about classroom tasks and activities"; 2) putting declarative lecture, procedural lecture, and technical lecture as sub-categories of lecture, item 7;3) breaking down item 8 of teacher talk in four sub-categories including "Begin the class", "End the class", "Monitor students' behavior", and "Assign homework".

Based on the original Flanders scale, the modified FIACS, and the adaptation of the scale for the study, FIACS used for data collection of this study has 12 major categories, which contain a total of 22 sub-categories of interaction (Table 1).

Prior to the study, the tool was tried out in an observation of a class where Chinese students were learning Thai in a private language school in Thailand. The class had three students and a Thai teacher. The class was observed for 45 minutes. The modified formulas were also tried out for the categorization of the 5 minutes record data in the pilot study. The Flanders scale and all the formulas were found applicable for the analysis process. 
Table 1. The modified Flanders scale

\begin{tabular}{|c|c|c|c|c|c|c|c|}
\hline \multicolumn{2}{|c|}{ Major category } & \multicolumn{2}{|c|}{ Second level category } & \multicolumn{4}{|c|}{ Sub-category } \\
\hline \multirow{13}{*}{$\begin{array}{l}\text { Teacher } \\
\text { talk }\end{array}$} & & 1 & \multicolumn{5}{|l|}{ Accept feeling } \\
\hline & & 2 & \multicolumn{5}{|l|}{ Praises or encourages } \\
\hline & & 3 & \multicolumn{5}{|c|}{ Accept or use ideas of students } \\
\hline & & 4 & \multicolumn{5}{|c|}{ Comments on students' answer } \\
\hline & & 5 & \multicolumn{5}{|c|}{$\begin{array}{l}\text { Giving direction about } \\
\text { classroom task and activities }\end{array}$} \\
\hline & & 6 & Ask questions & $\begin{array}{l}6.1 \\
6.2\end{array}$ & \multicolumn{3}{|c|}{$\begin{array}{l}\text { Ask open-ended questions } \\
\text { Ask closed questions }\end{array}$} \\
\hline & & \multirow{3}{*}{7} & \multirow{3}{*}{ Lecturing } & 7.1 & \multicolumn{3}{|c|}{ Declarative lecture } \\
\hline & & & & 7.2 & \multicolumn{3}{|c|}{ Procedural lecture } \\
\hline & & & & 7.3 & \multicolumn{3}{|c|}{ Technical lecture } \\
\hline & & \multirow{4}{*}{8} & \multirow{4}{*}{ Others } & 8.1 & \multicolumn{3}{|c|}{ Begin the class } \\
\hline & & & & 8.2 & \multicolumn{3}{|c|}{ End the class } \\
\hline & & & & 8.3 & \multicolumn{3}{|c|}{ Monitor students' behavior } \\
\hline & & & & 8.4 & \multicolumn{3}{|c|}{ Assign homework } \\
\hline \multirow{5}{*}{$\begin{array}{l}\text { Student } \\
\text { talk }\end{array}$} & \multirow{4}{*}{$\begin{array}{l}\text { Teacher-student } \\
\text { talk }\end{array}$} & \multirow{3}{*}{9} & \multirow{3}{*}{ Individually } & \multirow[b]{2}{*}{9.1} & \multirow{2}{*}{$\begin{array}{l}\text { Res } \\
\text { pons } \\
\text { e } \\
\end{array}$} & 9.1 .1 & Passively \\
\hline & & & & & & 9.1 .2 & Voluntarily \\
\hline & & & & 9.2 & $\begin{array}{l}\text { Initi } \\
\text { ate }\end{array}$ & & $\begin{array}{l}\text { Initiate to ask } \\
\text { questions }\end{array}$ \\
\hline & & 10 & Student respond colle & ely & & & \\
\hline & $\begin{array}{l}\text { Student-student } \\
\text { talk }\end{array}$ & 11 & Students communicat & ith ea & other & & \\
\hline \multirow{3}{*}{\multicolumn{2}{|c|}{ Silence }} & \multirow{3}{*}{12} & \multirow{3}{*}{ Silence or confusion } & 12.1 & \multicolumn{3}{|c|}{ contributes to teaching } \\
\hline & & & & 12.2 & \multicolumn{3}{|c|}{ does not contribute teaching } \\
\hline & & & & 12.3 & $\begin{array}{l}\text { cann } \\
\text { obser }\end{array}$ & $\begin{array}{l}\text { be ider } \\
\text { ation }\end{array}$ & ified by \\
\hline
\end{tabular}

\subsubsection{Classroom recording}

To accurately capture interaction in the observed classes, all three classes were video recorded. A camera was set up in the corner of the classroom where both the image and sound of the 
entire lessons were covered. As suggested by Dörnyei (2016), the record data provide a more objective account of events and behaviors than second-hand self-report data.

\subsubsection{Field notes}

In addition to the video records, field notes were also taken during observations to gather more comprehensive and missing information in the classroom. This is to avoid 'literal blind spots. As remarked by Zuengler, Ford, \& Fassnacht (1998), even though the video can help with uncovering the subtle reality of classroom life, it cannot avoid literal blind spots and the distraction caused by the camera will inevitably affect the data collection process.

\subsection{Data analysis}

\subsubsection{The analysis of Flanders scale and formulas}

The procedures for data analysis follow the initial research design by Flanders (1961) of encoding and decoding. With the recorded data from three "Thai Culture" classes, each of which lasted for about 2-3 hours, 30 minutes from each class was chosen as a representation which can be considered long enough compared with previous studies. With the selection of each 30 minutes, 5 minutes were taken as a unit of observation. The interval time between the six pieces of observation time was decided according to the length of the class. For example, the firstclass lasted for 120 minutes, so the interval time between every 5 minutes observation is 15 minutes $\left.(5+15)^{*} 6=120^{\prime}\right)$. After categorizing all the interactions in the classroom, a matrix was created to analyze the characteristics of the interactions. Because there are 22 sub-categories, a $22 \times 22$ matrix was created and each sub-category of interaction occupy one column and one row. The matrix finally contains 600 tallies from each of the three videos. After adding up "10" in the beginning and the end of the series, there are 602 tallies in each video. There are overall $601 \times 3=1803$ pairs of numbers in the summary matrix which includes the data of all three videos. The tallies from this matrix are used to calculate quantity, categories, and interaction characteristics, as shown in Table 2 and Table 3.

To ensure the accuracy of data coding, both researchers categorized the recorded data separately and then compared the two sets of analysis results. For the different categorizations of interaction, both researchers reviewed the video and discussed until they both agreed with the categorization.

\subsubsection{Transcription of class records and field notes}

Verbatim were transcribed from the 90-minute video records to show evidence of verbal interaction in different categories. Field notes were analyzed and quoted to merge all the data to answer the research questions. 


\section{Results}

To answer the research question on what the quantity, characteristics, and categories of teacher's talk and students' talk are based on a modified FIACS in a Thai language class where Chinese college students are studying Thai as a FL, findings are reported in three sections: 1) findings on the quantity of interaction; 2) findings on characteristics of interaction; and 3) findings on categories of interaction.

\subsection{Findings on the quantity of interaction}

Table 2 shows the quantity of interaction in percentage compared between the categories of Teacher Talk, Student Talk, and Silence based on the data gathered from the context of this study. In this table, C1 to $\mathrm{C} 22$ refer to all second-level categories and sub-categories of interaction as in Table 1.

Overall, the verbal interaction of the teacher categorized into 11 out of 14 types occupies 77 . $59 \%$; verbal interaction of the students categorized into 4 out of 5 types occupies $6.16 \%$; and silence categorized into all 3 categories takes up $16.25 \%$.

Most of the teacher talk covers the declarative lecture (45.04\%) and technical lecture (21.63\%) and ask open-ended questions (2.83\%) with no evidence of teacher procedural lecturing, ending class, and assigning homework. Most of the student talk covers passive responses by individual students $(2.44 \%)$ and students' communication with each other (2.11\%) without evidence of student initiation to ask questions. This shows a large gap between the teacher talk and the student talk. Field notes from observation also reflect the difference in the quantity of the talk of the teacher and the students. Silence covers almost three times as much of the student talk time.

Within the category of silence, silence or confusion that contributes to teaching takes up the highest percentage $(8.60 \%)$ of time. This covers a wider range of time than the silence that does not help teaching $(1.77 \%)$. During the time of silence, the teacher was observed to pause while lecturing to spend time writing or typing in front of the class and frequently searched for online materials. This led to the time of silence in class, which can be considered beneficial for the teaching-learning process. 
Table 2. Quantity and categories of interaction

\begin{tabular}{|c|c|c|c|c|c|c|}
\hline $\begin{array}{l}\text { Major } \\
\text { categorie } \\
\mathrm{s}\end{array}$ & $\begin{array}{l}2^{\text {nd }} \text { level } \\
\text { categories }\end{array}$ & & Sub-categories & $\begin{array}{l}\text { Freque } \\
\text { ncy }\end{array}$ & percen & tage \\
\hline \multirow{14}{*}{$\begin{array}{l}\text { Teacher } \\
\text { Talk }\end{array}$} & \multirow{5}{*}{$\begin{array}{c}\text { Indirect } \\
\text { Teacher Talk }\end{array}$} & $\mathrm{C} 1$ & Accept feeling & 3 & 0.167 & \multirow{5}{*}{-7.59} \\
\hline & & $\mathrm{C} 2$ & Praises or encourages & 3 & 0.16 & \\
\hline & & $\mathrm{C} 3$ & Accept or use ideas of students & 42 & $2.33\}$ & \\
\hline & & C6 & Ask open-ended questions & 51 & 2.83 & \\
\hline & & $\mathrm{C} 7$ & Ask closed questions & 38 & 2.11 & \\
\hline & \multirow{9}{*}{$\begin{array}{c}\text { Direct } \\
\text { Teacher Talk }\end{array}$} & $\mathrm{C} 4$ & Comments on students' answer & 11 & 0.617 & \multirow{9}{*}{70.00} \\
\hline & & $\mathrm{C} 5$ & $\begin{array}{l}\text { Giving direction about classroom } \\
\text { task and activities }\end{array}$ & 40 & 2.22 & \\
\hline & & $\mathrm{C} 8$ & Declarative lecture & 812 & 45.04 & \\
\hline & & C9 & Procedural lecture & 0 & 0.00 & \\
\hline & & $\mathrm{C} 10$ & Technical lecture & 390 & 21.63 & \\
\hline & & $\mathrm{C} 11$ & Begin the class & 5 & 0.28 & \\
\hline & & $\mathrm{C} 12$ & End the class & 0 & 0.00 & \\
\hline & & $\mathrm{C} 13$ & Monitor students' behavior & 4 & 0.22 & \\
\hline & & $\mathrm{C} 14$ & Assign homework & 0 & 0.00 & \\
\hline \multirow{5}{*}{$\begin{array}{l}\text { Student } \\
\text { Talk }\end{array}$} & & $\mathrm{C} 15$ & $\begin{array}{l}\text { Passively response by individual } \\
\text { student }\end{array}$ & 44 & 2.45 & \multirow{5}{*}{6.16} \\
\hline & $\begin{array}{l}\text { Teacher- } \\
\text { student talk }\end{array}$ & $\mathrm{C} 16$ & $\begin{array}{l}\text { Voluntarily response by individual } \\
\text { student }\end{array}$ & 19 & 1.05 & \\
\hline & & $\mathrm{C} 17$ & Student initiate to ask questions & 0 & 0.00 & \\
\hline & & $\mathrm{C} 18$ & Student respond collectively & 10 & 0.55 & \\
\hline & $\begin{array}{l}\text { Student- } \\
\text { student talk }\end{array}$ & $\mathrm{C} 19$ & $\begin{array}{l}\text { Students communicate with each } \\
\text { other }\end{array}$ & 38 & $2.11^{-}$ & \\
\hline \multirow{4}{*}{ Silence } & & $\mathrm{C} 20$ & $\begin{array}{l}\text { Silence or confusion that } \\
\text { contributes to teaching }\end{array}$ & 155 & 8.607 & \multirow{3}{*}{16.25} \\
\hline & & $\mathrm{C} 21$ & $\begin{array}{l}\text { Silence or confusion that does not } \\
\text { help teaching }\end{array}$ & 32 & 1.77 & \\
\hline & & $\mathrm{C} 22$ & $\begin{array}{l}\text { Silence that cannot be identified by } \\
\text { observation }\end{array}$ & 106 & $5.88-$ & \\
\hline & & & $\begin{array}{ll}\text { Total } \\
\end{array}$ & 1803 & 100 & 100 \\
\hline
\end{tabular}

\subsection{Findings on characteristics of interaction}

This section presents the findings on the characteristics of the interaction. Characteristics of teacher talk and student talk are calculated in ratio, as shown in Table 3.

For all the items, except for items four and seven, the first two columns show the corresponding number and the characteristics of the interaction percentage when put in the Flanders formula for calculation. The third column shows the modified formulas, and the fourth column displays the results after the calculation. Unlike other items, items 4 and 7 show the quantity and characteristics of interaction as well as the ratio between direct and indirect talk and the ratio 
between positive and negative reinforcement, respectively. Rather than being calculated in percentage, the number shown in these two items is the ratio.

Table 3. Percentage and ratio of interaction based on the Flanders Formulas

\begin{tabular}{|c|c|c|c|}
\hline NO. & Type & Formula & Results \\
\hline 1 & Teacher Talk Ratio (TT) & $\frac{C 1+C 2+C 3+C 4+C 5+C 6+C 7+C 8}{\text { The total number of categories }} \times 100$ & 77.59 \\
\hline 2 & $\begin{array}{c}\text { Indirect Teacher Talk Ratio } \\
\text { (ITT) }\end{array}$ & $\frac{C 1+C 2+C 3+C 6}{\text { The total numberof categories }} \times 100$ & 7.6 \\
\hline 3 & $\begin{array}{c}\text { Direct Teacher Talk Ratio } \\
\text { (DTT) }\end{array}$ & $\frac{C 4+C 5+C 7+C 8}{\text { The totalnumberof categories }} \times 100$ & 69.99 \\
\hline 4 & $\begin{array}{l}\text { Indirect and Direct Ratio } \\
\text { (I/D)* }\end{array}$ & $\frac{C 1+C 2+C 3+C 6}{C 4+C 5+C 7+C 8}$ & 0.11 \\
\hline 5 & $\begin{array}{c}\text { Teacher Response Ratio } \\
\text { (TRR) }\end{array}$ & $\frac{C 1+C 2+C 3}{C 1+C 2+C 3+C 4+C 5+C 8} \times 100$ & 44.44 \\
\hline 6 & $\begin{array}{l}\text { Teacher Question Ratio } \\
\text { (TQR) }\end{array}$ & $\frac{C 6}{C 6+C 7} \times 100$ & 6.89 \\
\hline 7 & $\begin{array}{l}\text { Teacher positive } \\
\text { reinforcement and negative } \\
\text { reinforcement ratio* }\end{array}$ & $\frac{C 1+C 2+C 3}{C 4+C 5+C 8}$ & 0.27 \\
\hline 8 & Pupil’s Talk Ratio (PT) & $\frac{C 9+C 10+C 11}{\text { The total number of categories }} \times 100$ & 6.16 \\
\hline 9 & Pupil Initiation Ratio (PIR) & $\frac{C 9.2}{C 9+C 10+C 11} \times 100$ & 0 \\
\hline 10 & $\begin{array}{l}\text { Content Cross-Ratio } \\
\text { (CCR) }\end{array}$ & $\frac{C 6+C 7}{\text { The total number of categories }} \times 100$ & 71.6 \\
\hline 11 & Steady State Ratio (SSR) & $\frac{\text { Total } 12 \text { diagonal cells }}{\text { The total number of categories }} \times 100$ & 83.69 \\
\hline 12 & $\begin{array}{l}\text { Silence or Confusion Ratio } \\
\text { (SC) }\end{array}$ & $\frac{C 12}{\text { The total number of categories }} \times 100$ & 16.25 \\
\hline
\end{tabular}

\subsubsection{Teacher Talk}

Based on items 1-7 and 10, teacher talk ratio reflects four characteristics of teacher talk: 1) direct or indirect; 2) teacher's asking and responding to questions; 3) teacher's positive and negative reinforcement; and 4) teacher's questions and lecture in relation to the total number of categories.

\subsubsection{Indirect and Direct Talk}

Regarding the ratio of indirect and direct talk, which is 0.11 , teacher's talk is much more direct than indirect. The teacher tended to comment on students' answers, give directions about classroom tasks and activities, lectures, give short talks to begin the class, and make statements 
to monitor students' behavior rather than to accept students' feelings, praise or encourage them, accept or use their ideas, and ask them questions. Praises and encouragement are rarely found in the teacher's talk.

\subsubsection{Asking and Responding to Questions}

Items 5 and 6 in Table 3 show the Teacher Response Ratio (TRR), which indicates the teacher's tendency to react to the ideas and feelings of the students. The ratio provides an index of the emotional climate in the classroom. As found in this study, the TRR is $44.44 \%$. This shows that the teacher sometimes responded to the students. When she responded to the students, the teacher was observed to repeat the students' answers but not to use them. The most common way of the teacher responding to the students was to repeat students' answers. The repetition of the students' answers was observed to show the teacher's agreement of students' answers. The extension of the students' answers was rarely observed. Accordingly, the interaction between the teacher and students was observed to be in the form of simple and short sentences. Comments on students' answers, and praise or encouragement were rarely found.

Teacher Question Ratio (TQR), which points to the tendency of the teacher to ask questions during the content-oriented part of the class, is $6.89 \%$. The low number reveals that the teacher tended not to ask questions during the time spent to focus on the content. Data from observations and field notes also reveal that the same questions were asked to every student in the classroom.

\subsubsection{Positive and Negative Reinforcement}

Item 7 in Table 3 shows the ratio of positive reinforcement and negative reinforcement provided by the teacher. The positive teacher reinforcement and negative reinforcement ratio of this study are 0.27 . This indicates rare evidence of the teacher accepting students' feelings, praising or encouraging them, and accepting or using their ideas. Observation data also support this finding.

\subsubsection{Content Cross-Ratio}

Item 10 in Table 3 shows Content Cross-Ratio (CCR), which indicates the emphasis given to the content coverage during classroom transactions, which shows the percentage of time that the teacher uses to focus on the content by lecturing and asking questions. The ratio of this study is $71.6 \%$. This means that the teacher frequently spent the time lecturing and asking questions out of the total time recorded. Observations and field notes offer evidence of the teacher talking about the content, reflecting a marginally high degree of lecturing than asking questions.

\subsubsection{Student Talk}

Item 8 shows Pupil's Talk Ratio (PT), which refers to the verbal interaction of students in the classroom. The PT ratio of $6.16 \%$ represents the students' amount of time in the total recorded class time (90 minutes). This finding reflects that the students rarely talked during the class.

Item 9 shows Pupil Initiation Ratio (PIR), which indicates that the proportion of students' talk is judged to be an act of initiation. The PI ratio of zero means that the students never initiated any talk in the classes observed. Field notes revealed that students answered the teacher's questions voluntarily or passively, and together or individually. The answering of questions individually and passively occupies the largest proportion in students' talk. When the teacher raised a question to the class, only a few students answered. One student was observed to refuse 
to join the writing activity in class. The students were also observed to talk among themselves when the teacher raised a question and while the teacher was teaching.

\subsubsection{Steady-State Ratio}

Item 11 in Table 3 shows the Steady State Ratio (SSR). This is an index that represents a sustained level of verbal interchange and steady talk between teacher and students. This formula reflects the teacher and students' tendency to remain in the same category for periods longer than 3 seconds. The high percentage SSR ratio of $83.69 \%$ reflects that the teacher talk, the student talk, and silence usually remain steady in the same category.

\subsubsection{Silence}

Item 12 in table 3 indicates Silence or Confusion Ratio (SC), which refers to the percentage of time that silence filled up the classroom. This study's silence ratio was $16.25 \%$ of the total teaching recorded time (90 minutes). Field notes and recording data show that silence occurred after the teacher asked a question while the teacher was fixing, teaching her PowerPoint slides, or dealing with the problems of technological equipment.

\subsection{Findings on categories of interaction}

Verbatim transcribed from the video illustrates both teacher and student talk in some categories. The categories of talk can be referred to in Table 1 .

\subsubsection{Categories of teacher talk}

Below are examples of statements made by teachers to accept the feelings of the students are the following:

At one point, the teacher encouraged a student to participate in class by writing a Thai word on board in front of the class. The student refused to do so but said he could say it. The teacher acknowledged the student's choice to speak instead of writing. The conversation ended there without the student saying a word and with the teacher moving on with her own saying of the word.

Teacher: Come, come and write. (with handing the marker to a student)

Student: I can just speak. (In fact, this student did not say anything after that)

Teacher: Alright, you can speak.

(transcription of class one observation between 01:02:26-01:02:32 mins from the second video)

Here is a conversation capturing what the teacher said to accept or use ideas of the students from the third video. Student A was assigned to ask a riddle and some classmates answered at the same time. The teacher always repeated the students' answers. Comments on the students' answers were minimal.

Student A: What has two ears and four eyes, feeling so bored and putting legs on the ears? students: Glasses.

Teacher: This, two ears and four eyes.

Student B: Frying pan.

Teacher: The answer is already glasses. (the class laughed)

(transcription of class one observation between 48:36-49:12 mins from the third video)

This is another example to illustrate that the teacher accepted or used ideas of students by 
repeating and extending students' answers.

Student A: กาล [A Thai word referring to time]

Teacher: Ahh, it means "time", right? Ok, how about student B's answer?

Student B: 'จาก' or บริ ‘จาค' [A Thai word referring to "leave" or a part of the word that means domate จาก and จาค in Thai are pronounced the same way, but the meaning can be different depending on the context and the prefix.]

Teacher: How to write it?

Student B: จอจาน สระอา กอไก่ [the student spelt in Thai]

Teacher: จอจาน สระอา กอไก่ จอจาน สระอา กอไก่ [the teacher repeated the student's answer twice] There are two words with this pronunciation, right? One means "leave", and the other one is one part in the word "donate", right?

Student B: Yes.

Teacher: OK, yes.

(transcription of class one observation between 12:26-13:00 mins from the second video)

The following verbatim also illustrates how the teacher interacts with students by repeating the questions and the students' answers, as well as the students' short answer.

Teacher: A, do you know any northern language?

Student A: (in low voice)

Teacher: What?

Student A: ซาวบาท (20 baht in northern Thai language)

Teacher: It means what?

Student: $\quad 20$ baht.

Teacher: 20 baht, ok.

Teacher: B, Do you know any northern languages?

Student B: (A Thai word)

Teacher: (Repeat), it means what?

Student B: Don't want it.

Teacher: Don't want it. Ok, C, do you know any northern language?

(transcription of class one observation between 26:51-27:06 mins from the first video)

Directions for classroom tasks and activities are found in the following two pieces of verbatim. The first one occurred when the teacher required each student to find a riddle and share with the class, but the students kept silent.

Teacher: Go on, go on, the one who finishes first can go home first.

(transcription of class one observation between 49:24-49:30 mins from the third video)

The second conversation happened when the teacher encouraged the students to write a Thai word with a specific sound on the whiteboard. The teacher kept giving more directions and guidance when the students stayed passive, and at last, she asked one of the students to write on the whiteboard.

Teacher: It needs to be the "an" sound, the "an" sound; any alphabet will work. Silence time from 01:03:59 to 01:04:32, some students were discussing with classmates in low voices. 
Teacher: Can be any word with the "an" sound.

Student A: (A Thai word)

Teacher: (repeated) Come to write it.

Then the student went to write it out on the whiteboard.

(transcription of class one observation between 01:03:50-01:05:29 mins from the second video)

Questions the teacher asked included both open-ended and closed-ended questions. This kind of pattern of questioning and answering questions was found to be common and consistent in all the video records. Open-ended questions were observed to be only those that required memory or recalled information. Only recall and memory questions were typically asked.

Teacher: A, do you know any northern Thai words?

Student A: Yes, I know.

Teacher: $\quad$ Ok, which word do you know?

Student A: [The student answered 5 northern Thai words]

Teacher kept saying "Uh-huh" in the beginning, and later started to repeat each word after the student.

Teacher: It's ok, share some with your friends, leave them some words.

Teacher: “จักกิ้ม" [a northern Thai word means "lie"] means what?

Students: ขี้ขุ้ [means "lie" in Thai, the students said this word together]

Teacher: It means what?

Student B: Lie.

Teacher: Lie, ok.

(transcription of class observation between 27:54-28:27 mins from the first video)

Teacher talk also included motoring of students' behavior which is shown as below.

Teacher: Come late.

(transcription of class observation between 10:39-10:42 mins from the first video)

Teacher: Loudly.

(transcription of class observation between 27:21-27:24 mins from the first video)

\subsubsection{Categories of student talk}

Most of the students talk among themselves happened after the teacher's question. This conversation occurred when the teacher was encouraging and waiting for someone to write an answer in front of the class.

Teacher: So who's gonna come to write?

Student A: Student B.

Student B: Not me, not me.

Student A: It should be you, you figured it out.

[Then Student B came to write.]

(transcription of class observation between 01:03:38-01:03:50 mins from the second video)

Each student was assigned to do an activity by looking for a riddle from the Internet to ask the class to solve it. This conversation happened when one of the students asked the class to solve 
a riddle, and two other students were discussing the answer.

Student A: It should be walking all the time, if it stops, it dies.

Student B: She said it's "clock".

(transcription of class observation between 47:33-47:45 mins from the third video)

This conversation ended with the teacher continuing to ask other students to share their riddles.

\section{Discussion}

Interaction in the classroom under investigation takes into account quantity, characteristics, and categories of teacher and student talk, as well as silence that fills up the classroom. All these aspects of the interaction are interrelated; therefore, they are discussed as interrelated. This leads to three points of discussion: quantity of interaction; quality of interaction, which involves characteristics and categories of teacher and student talk; and role of silence. Another point of discussion is how the findings provide insights into pedagogical perspectives in general.

\subsection{Quantity of interaction}

In the context of this study, the teacher was found to be the main interlocutor in oral activities and played the dominant role in class. This provides similar findings to some previous studies using the FIACS (Mulyati, 2013; Nugroho, 2011; Putri \& Pulungan, 2014). This is considered normal as teachers have the power to distribute learning opportunities for students because of their institutional status (Hall, 1997) as well as their identities (Jeanjaroonsri, 2018). However, according to Afrin (2018) and Gündüz (2014), teachers' dominant speech in a language classroom can negatively affect students' language learning results. In addition to the high quantity of talk, the high percentage Steady State Ratio (83.69\%) also reflects that the teacher kept lecturing for a long time. In such a continuous one-way teaching process of the teacher, the students could only passively accept the information transmitted by the teacher. This leads to insufficient opportunities for students to actively participate in the interaction. They were neither given enough opportunities to talk to each other, and their interactions were not conducive to their studying. In fact, the interaction between students has also been proved to be beneficial to students' language learning and social outcomes (Webb,1982; Webb, 1984; Battistich, Solomon \& Delucchi, 1993).

Despite this finding, however, the teacher was observed trying to encourage the students to participate at some points during the lesson, but the students remained unresponsive. The teacher was observed to repeat her questions several times, provided more clues, gave the students alternative ways of responding such as writing the response onboard instead of an oral response and even provided a long and adequate wait time. Relevant research, including that of second language acquisition, in fact, indicates that students' individual differences (Hoang, 2021) and personal characters such as motivation (Nugroho, 2017), confidence (Fassinger, 1995), nervousness (Smith, 1992), shyness (McCroskey \& Richmond, 1991), being afraid of making mistakes, being compared with peers, and being corrected by others (Smith, 1992) are found to be factors to affect students' interaction.

What is more, although previous scholars put emphasis on the importance of students' talking time in foreign language classrooms (Paul, 2003), the quantity of interaction is not directly related to the quality of interaction, and adequate interaction cannot guarantee efficient language learning (Zhao, 2013). Therefore, reducing the teacher talking time alone can increase the student talk or not is still questionable. 


\subsection{Quality of interaction (characteristics and categories of interaction)}

In some studies, teachers are not the center of the classroom, and the proportion of students speaking is very high, but the results show that the quantity of students taking the initiative to speak is very small (Bonavetti, 2015). Students' initiation has been proved to promote comprehensible input and output and thus language learning (Garton, 2002). In this study, "Passively response by individual students" takes the largest proportion in students' talk, and "Initiate to ask questions" was not found. This leads to another question on the quality of interaction which is related to the characteristics and categories of teacher and student talk.

Previous studies have also shown that teacher-related factors such as teaching style, the difficulty of materials, the content of class (Mustapha \& Rahman \& Yunus, 2010), intelligibility of directions (Abebe \& Deneke, 2015), the length of wait time for students to answer questions (Tsui, 2001), and the grouping strategies that the teacher use during activities; for example, individual, pair, or group work (Riasati, 2012; Tsui, 2001), praises and encouragement (Smith, 1992; Liu, 2001), teacher questioning (Tsui, 2001), and teacher feedback (Brinton, 2014) affect students' interaction. Evidence from this study pinpoints the effects of some of these factors.

The teacher rarely accepted students' feelings, praised and encouraged them, nor accepted and used their ideas. Whether the teacher praises and encourages students when they make efforts in class also affect students' utterances (Smith, 1992; Liu, 2001). In the classrooms observed, when the students answered the teacher's questions correctly, the teacher acknowledged the students' answers only by repeating them. The students were neither praised for their responses nor encouraged to expand their answers.

Teacher questioning is another factor found to affect the students' interaction. Data show that the teacher asked closed-ended and open-ended questions with relatively equal proportions. The open-ended questions asked, however, were recall or memory questions. The teacher was observed to intentionally ask these types of questions to elicit the students' talk as much as possible while the students still rarely responded. Since the questions required the same information as the answers, when the students answered as the whole class, only some said the answers. Students' insufficient expression to teachers will also lead to insufficient feedback from teachers; that is, the interactive cycle between teachers and students cannot be completed. Tsui (2001) maintains that "teacher question" is one of the crucial components in teacher-related factors that affect students' interaction. This is because the complexity of the questions asked by the teacher decides the number of responses from the students.

\subsection{Role of silence}

In this study, the time of silence or confusion occupies almost three times as much as the students' talk. The silence was observed to occur mainly after the teacher asked questions. Bolitho (2006) claims that high-quality talk frequently includes thoughtful silences. According to his view of points, the type of silence which can take place after a good question is "educationally valuable because it promotes thinking, and if it happens frequently, students will come to understand it and make use of it as a time for them to order their thoughts and to find the right way of expressing them". Based on the researcher's observation and video record, the students' silence usually ended up with one of the students replying with the correct answer, meaning that students were actively thinking about the question. This indicates that such silence is beneficial. Other situations where silence usually took place were when the teacher spent time on her own in front of the class, modifying slides, dealing with the teaching equipment, 
and writing or typing slides for students. The previous study claims that excessive silence can have various negative effects, as it is the absence of L2 oral practice (Cardenas, 2013). Therefore, attention should be paid to the amount of silent time, whether it supports the teaching and learning process or not, especially in a foreign language classroom.

\subsection{Pedagogical perspective}

Generally, findings suggest the target classroom be teacher-centered since the teacher had the primary responsibility (Mascolo, 2009). As opposed to student-centered classrooms, negative effects are caused by teacher-centered classrooms, such as the inadequacy of opportunities for the students to interact. Still, as suggested by Murphy, Eduljee, and Croteau (2021), some previous research studies inform that students prefer teacher-centered teaching methods. These students prefer teachers to help them impart and construct knowledge and skills (Serin, 2018). The point is not whether a teacher-center classroom should be replaced with a student-center classroom or not, but that teachers are recommended to evaluate the effectiveness of their teaching that promotes active learning. Foreign language teachers are particularly recommended to engage students in using the language in real-life contexts as much as possible, and interaction among the students themselves is also needed (Hismanoglu \& Hismanoglu, 2011).

\section{Conclusion}

This mix-method study is conducted based on the Flanders Interaction Analysis Category System (FIACS) in an FL classroom where Chinese students learn Thai.

In-depth data provides insights into a better understanding of the situations in which teachers tend to play a dominant role in class. With the teachers playing more of a role, the process of information exchange (Hanum, 2017) between teachers and students and among the students might not be smooth. Students' communication, cognitive, and social ability (Brown \& Lee, 2015) might not be well developed. Language teachers, in particular, are recommended to be mindful of the quantity of their role in class, not to limit the students' opportunities to play their role. As well, they are recommended to pay attention to improving the quality of their interaction to support the students' learning and help students improve the quality of their interaction. In language teaching and learning, especially foreign language learning, as in this study, Chinese students' first language is totally different from Thai as a foreign language; teachers need to try harder to understand their students. If teachers can find out what makes the students refrain from class participation, they can better apply strategies or techniques to create, sustain, and expand the students' interaction. Various methods of increasing students' talking time, especially voluntary talking time, should be conducted. The silence time can also be beneficial as long as the content and amount are suitable in an FL classroom.

The generalization of the findings of this study must be taken with caution due to the limitation of the number of participants (twenty-eight students and one teacher). This study focuses on only verbal interaction. 


\section{References}

Adaba, H.W. (2017). Exploring the practice of teacher-student classroom interaction in EFL to develop the learner's speaking skills in Tullu Sangota primary school grade eight students in focus. Art and Social Science Journal, 8(4), 1-18. DOI: 10.4172/21516200.1000295 .

Abebe, D., \& Deneke, D. (2015). Causes of students' limited participation in EFL classroom: Ethiopian public universities in focus. International Journal of Educational Research and Technology, 6(1), 74-89.

Almohizea, N. I. (2018). An investigation of oral interaction in English as a foreign language classroom. International Journal of Language and Linguistics, 6(3), 51-60. DOI:10.11648/j.ij11.20180603.11

Allwright, R. L. (1984). The importance of interaction in classroom language learning. Applied linguistics, 5(2), 156-171. https://doi.org/10.1093/applin/5.2.156

Amatari, V. O. (2015). The instructional process: a review of Flanders' interaction analysis in a classroom setting. International Journal of Secondary Education, 3(5), 43-49. DOI: 10.11648/j.ijsedu.20150305.11

Allen, J. P., Pianta, R. C., Gregory, A., Mikami, A. Y., \& Lun, J. (2011). An interaction-based approach to enhancing secondary school instruction and student achievement. Science (New York, N.Y.), 333(6045), 1034-1037. https://doi.org/10.1126/science.1207998

Allen, J., Gregory, A., Mikami, A., Lun, J., Hamre, B., \& Pianta, R. (2013). Observations of Effective Teacher-Student Interactions in Secondary School Classrooms: Predicting Student Achievement With the Classroom Assessment Scoring System-Secondary. School psychology review, 42(1), 76-98.

Afrin, T. (2018). The role of classroom interaction in improving learners speaking skills: a case study of private universities (Doctoral dissertation, BRAC University).

Bolitho, R. (2006). Teacher talk and learner talk. European Center for Modern Languages of the Council of Europe. http://archive.ecml.at/mtp2/grouplead/results/lucru/4/rod.pdf

Battistich, V., Solomon, D., \& Delucchi, K. (1993). Interaction processes and student outcomes in cooperative learning groups. The Elementary School Journal, 94(1), 19-32. http://www.jstor.org/stable/1001872

Bonavetti, M. C. (2015). Oral interaction in the classroom: An up-close view at the English as a Foreign Language Teaching Program at Universidad Adventista del Plata. Enfoques, 27(1), 51-77.

Bin, W. (2009). Coping with culture shock: a study of stressors, adjustments and stereotypes among Chinese students at Bangkok University. Master Dissertation, Bangkok University, Thailand. http://dspace.bu.ac.th/jspui/handle/123456789/569

Brinton, D. M. (2014). Tools and techniques of effective second/foreign language teaching. Teaching English as a second or foreign language, 340-361.

Brown, H. D. (2000). Principles of language learning and teaching (Vol. 4). New York: Longman. 
Brown, H. D., \& Lee, H. (2015). Teaching principles. P. Ed Australia.

Blosser, P. E. (1991). How to ask the right questions. NSTA Press.

Choudhury, S. (2005). Interaction in second language classrooms. BRAC University Journal, 2(1), 77-82.

Cardenas, F. L. (2013). Teacher talking time vs. student talking time: Fostering speaking in the EFL classroom. Universidad Austral de Chile.

Carless, D. (2008). Student use of the mother tongue in the task-based classroom. ELT Journal, 62(4), 331-338. DOI:10.1093/elt/ccm090

Chaudron, C. (1988). Second Language Classrooms. Research on Teaching and Learning. Cambridge University Press, 40 West 20th Street, New York, NY 10011.

Cheewagaroon, R. (2011). Teaching Change in Response to Thai Tertiary English Language Teaching Reform. Unpublished doctoral dissertation, University of Wollongong, Australia.

Dörnyei, Z. (2016). Research methods in applied linguistics. Oxford: Oxford University Press.

Evans, T. P. (1970, March). Flanders System of Interaction Analysis and Science Teacher Effectiveness. The Forty-Third Annual Meeting of the National Association for Research in Science Teaching, Minneapolis, Minnesota.

Fang, L., \& Chalermnirundorn, N. (2019, August). A Study of Chinese University Students' Perceptions towards Thai Language in Yunnan Province, China. In Rangsit Graduate Research Conference: RGRC (Vol. 14, pp. 0109-0117).

Flanders, N. A. (1961). Analyzing Teacher-Behavior. Educational leadership, 19(3), 173.

Flanders, N. A. (1965). Teacher Influence, Pupil Attitudes and Achievement, US Government Printing Office.

Flanders, N. A. (1966). Interaction analysis in the classroom: A manual for observers. Ann Arbor, Mi: School of Education, University. of Michigan.

Fassinger, R. E. (1995). From invisibility to integration: Lesbian identity in the workplace. The Career Development Quarterly,44(2), 148-167. https://doi.org/10.1002/j.21610045.1995.tb00682.x

Fan, S. (2010). Language shock: A challenge to language learning. Internet Journal of Language, Culture and Society, 2(31), 51-42. www.educ.utas.edu.au/users/tle/JOURNAL/

Fazio, L., \& Lyster, R. (1997). Colt comparisons of second language learning environments in minority language and immersion classrooms. Manuscript submitted for publication.

Ginting, S.A. (2017). The importance of opening moves in classroom interaction. Advanced in Language and Literary Studies, 8(6), 7-11.

Gupta, D. (2004). CLT in India: Context and methodology come together. ELT Journal, 58, 266-269. DOI:10.1093/elt/58.3.266

Gündüz, M. (2014). Analyzing language classrooms through classroom interaction. Journal of human sciences, 11(2), 1149-1166. DOI:10.14687/ijhs.v11i2.3044 
Garton, S. (2002). Learner initiative in the language classroom. ELT journal, 56(1), 47-56. https://doi.org/10.1093/elt/56.1.47

Hao, Y. S. (2007). Behavior analysis of college students' classroom participation. Research on Higher Engineering Education, (6), 131-134.

Hadfield, J., \& Hadfield. (2008). Introduction to teaching English. Oxford: Oxford university press.

Hanum, N. S. (2017, June). The importance of classroom interaction in the teaching of reading in junior high school. In Prosiding Seminar Nasional Mahasiswa Kerjasama Direktorat Jenderal Guru dan Tenaga Kependidikan Kemendikbud 2016.

Harmer, J. (2008). How to teach English. ELT journal, 62(3), 313-316. https://doi.org/10.1093/elt/ccn029

Hall, J. K. (1997). Differential teacher attention to student utterances: The construction of different opportunities for learning in the IRF. Linguistics and Education, 9(3), 287311. https://doi.org/10.1016/S0898-5898(97)90003-6

Hismanoglu, M., \& Hismanoglu, S. (2011). Task-based language teaching: what every EFL teacher should do. Procedia Social and Behavioral Sciences 15, 46-52. https://doi.org/10.1016/j.sbspro.2011.03.049

Hoang, V. Q. (2021). The Differences of Individual Learners in Second Language Acquisition. International Journal of TESOL \& Education, 1(1), 38-46. Retrieved from http://i-jte.org/index.php/journal/article/view/6

Hughes, Jan \& Cavell, Timothy \& Willson, Victor. (2001). Further Support for the Developmental Significance of the Quality of the Teacher-Student Relationship. Journal of School Psychology. 39. 289-301. 10.1016/S0022-4405(01)00074-7. DOI:10.1016/S0022-4405(01)00074-7

Hughes, J. N., \& Cavell, T. A. (1999). Influence of the teacher-student relationship in childhood conduct problems: A prospective study. Journal of clinical child psychology, 28(2), 173 184. https://doi.org/10.1207/s15374424jccp2802_5

Hedge, T. (2000). Teaching and Learning in the Language Classroom. Oxford: Oxford University Press.

Hullen, W. (1989). Investigations into classroom discourse. 1989), Current Trends in European Second Language Acquisition Research, Clevedon, Avon, Multilingual Matters.

Indoshi, F. C., Bett, J., \& Odera, F. Y. (2009). The nature of interaction in English language classrooms. The International Journal of Learning, 16(7), 217 - 227.

Jeanjaroonsri, R. (2018). A Study of Constructive or Restrictive Features of Classroom Discourse in an EFL Adult Classroom in Thai Context. LEARN Journal: Language Education and Acquisition Research Network, 11(1), 125-139.

Kayi, H. (2006). Teaching speaking: Activities to promote speaking in a second language. The internet TESL journal, 12(11), 1-6.

Long, M. (1996). The role of the linguistic environment in second language acquisition. Open Journal of Modern Linguistics, 2(2), 413-468. 
Luo, X. (2016). Factors Positively Affecting Chinese Students'Loyalty towards Universities in Bangkok. Master's thesis, Bangkok University, Bangkok, Thailand.

Liu, J. (2001). Asian students' classroom communication patterns in US universities: An emic perspective. Greenwood Publishing Group.

Mascolo, M. F. (2009). Beyond student-centered and teacher-centered pedagogy: Teaching and learning as guided participation. Pedagogy and the human sciences, 1(1), 3-27.

McCroskey, J. C., \& Richmond, V. P. (1991). Quiet children and the classroom teacher. ERIC Clearinghouse on Reading and Communication Skills, Indiana University, 2805 E. 10th St., Suite 150, Bloomington, IN 47408-2698.

Mustapha, S. M., Abd Rahman, N. S. N., \& Yunus, M. M. (2010). Factors influencing classroom participation: a case study of Malaysian undergraduate students. ProcediaSocial and Behavioral Sciences, 9, 1079-1084. https://doi.org/10.1016/j.sbspro.2010.12.289

Murphy, L., Eduljee, N. B., \& Croteau K. (2021). Teacher-centered versus student-centered teaching: Preferences and differences across academic majors. Journal of Effective Teaching in Higher Education 4(1), $18-39 . \quad 1$ DOI:https://doi.org/10.36021/jethe.v4i1.156

Mulyati, A. (2014). A study of teacher talk and student talk in verbal classroom interaction to develop speaking skill for young learners. Journal of English and Education, 1(1), 110. Retrieved from https://ejournal.upi.edu/index.php/L-E/article/view/318/208

Mu, A. L., Lv, K. Y., \& Wang, X. M. (2014). Improvement of coding standard of Flanders interactive analysis system. Хиеуиаn, (20),10-11

Nafi, N. N., Rinanda, D., \& Sularti, S. (2019). The Adjacency Pairs Analysis of Teacher Students Talks in Hearing Impairment Classroom. Register Journal, 12(1), 81-99. DOI: https://doi.org/10.18326/rgt.v12i1.81-99

Nghiem, H. S., Le, T. T. K., Ly, T. N. A., Tang, V. Y., \& Phan, T. T. M. (2021). Difficulties when studying away from home. International Journal of TESOL \& Education, 1(1), 1-12. Retrieved from http://i-jte.org/index.php/journal/article/view/1

Nida, E. A. (2003). Principles of correspondence. In Toward a science of translating (pp. 156192). Brill. https://doi.org/10.1163/9789004495746_010

Nunan, D. (1991). Communicative tasks and the language curriculum. TESOL quarterly, 25(2), 279-295. https://doi.org/10.2307/3587464

Nunan, D. (1991). Understanding language classrooms: A guide for teacher-initiated action. Prentice Hall.

Nugroho, P. (2017). Factors affecting the students' reluctance to speak English in classroom interaction. Retrieved from http://repo.iain-tulungagung.ac.id/6475/7/BAB IV.pdf

Nugroho, K. (1). Interaction in English as a Foreign Language Classroom (A Case of Two State Senior High Schools in Semarang in the Academic Year 2009/2010). English Education Journal, 1(1). Retrieved from https://journal.unnes.ac.id/sju/index.php/eej/article/view/148 
Paul, David. (2003). Teaching English to children in Asia. Hong Kong : Longman Asia ELT

Putri, F. G., \& Pulungan, R. (2014). An analysis of classroom interaction by using Flanders Interaction Analysis Categories System (FIACS) technique at SMPN 13 Kota Bengkulu in 2013/2014 academic year (Doctoral dissertation, Universitas Bengkulu).

Rahman, M. S. (2017). The Advantages and Disadvantages of Using Qualitative and Quantitative Approaches and Methods in Language "Testing and Assessment" Research: A Literature Review. Journal of Education and learning, 6(1), 102-112. http://dx.doi.org/10.5539/jel.v6n1p102

Rivers, W. M. (1987). Interactive language teaching. Cambridge University Press, 40 West 20th Street, New York, NY 10011 (hardcover--ISBN-0-521-32216-2; paperback-ISBN-0-521-31108-X).

Riasati, M. J. (2012). EFL students' perception of factors influencing willingness to speak English in language classrooms: A qualitative study. World Applied Sciences Journal, 17 (10), 1287-1297.

Romanel, C., \& Kundu, T. (1993). A hybrid modelling of soil-structure interaction problems for deeply embedded structures in A multilayered medium. Earthquake Engineering \& Structural Dynamics, 22(7), 557-571. https://doi.org/10.1002/eqe.4290220702

Serin, H. (2018). A comparison of teacher-centered and student-centered approaches in educational settings. International Journal of Social Sciences \& Educational Studies, 5(1), 164-167. https://doi.org/10.23918/ijsses.v5i1p164

Sundari, H. (2017). Classroom interaction in teaching English as FL at lower secondary schools in Indonesia. Advances in Language and Literary Studies, 8(6), 147-154. DOI: http://dx.doi.org/10.7575/aiac.alls.v.8n.6p.147

Smith, D. H. (1992). Encouraging students' participation in large classes: A modest proposal. Teaching Sociology, 20(4), 337-339. https://doi.org/10.2307/1318983

Sakui, K. (2004). Wearing two pairs of shoes: Language teaching in Japan. ELT Journal, 58, 155-163. https://doi.org/10.1093/elt/58.2.155

Singh, Y. K., Sharma, T. K., \& Upadhya, B. (2008). Educational Technology: Teachinglearning. APH.

Malamah-Thomas, A. (1987). Classroom Interaction. Oxford University Press.

Tsui, A. B. (2001). Classroom interaction. The Cambridge guide to teaching English to speakers of other languages, 120-125.

Taous, B. (2013). The role of classroom interaction in improving the students' speaking skill. Biskra University.

Webb, N. M. (1982). Group composition, group interaction, and achievement in cooperative small groups. Journal of Educational Psychology, 74(4), 475. https://doi.org/10.1037/0022-0663.74.4.475

Webb, N. M. (1984). Stability of small group interaction and achievement over time. Journal of Educational Psychology, 76(2), 211. https://doi.org/10.1037/0022-0663.76.2.211

Wiriyachitra, A. (2002). English language teaching and learning in Thailand in this decade. 
Thai TESOL Focus, 15(1), 4-9.

Ye, Y. (2020). Factors affecting the decision-making of the Chinese students to study in higher education institutions in Thailand. Romphruek Journal 38(1), 102-117

Yin, H., Ruangkanjanases, A., \& Chen, C. (2015). Factors Affecting Chinese Students' Decision Making toward Thai Universities. International Journal of Information and Education Technology. 5(3), 189-195. DOI: 10.7763/IJIET.2015.V5.500

Zuengler, J., Ford, C., \& Fassnacht, C. (1998). Analyst Eyes And Camera Eyes: Theoretical and Technology Considerations in "Setting" The Details of Classroom Interaction. Albany, N.Y.: School of Education, University at Albany.

Zhao, C. (2013). Classroom Interaction and Second Language Acquisition: The More interactions the Better?. Studies in Literature and Language, 7(1), 22-26. DOI: http://dx.doi.org/10.3968/n

\section{Biodata}

Kailing Zhao is a Chinese student who is currently pursuing a Master of Arts in Applied Linguistics (Faculty of Liberal Arts, Mahidol University, Thailand). Her research interests include foreign language teaching and intercultural communication.

Kornsiri Boonyaprakob $(\mathrm{PhD})$ is a faculty member in international graduate programs in Applied Linguistics, Faculty of Liberal Arts, Mahidol University, Thailand. Her research covers topics on teaching and learning, and student development. 